Article

\title{
Numerical Evaluation of a HVAC System Based on a High-Performance Heat Transfer Fluid
}

\author{
Gianpiero Colangelo*(D), Brenda Raho (D), Marco Milanese (D) and Arturo de Risi \\ Department of Engineering for Innovation, University of Salento, SP per Monteroni, 73100 Lecce, Italy; \\ brenda.raho@studenti.unisalento.it (B.R.); marco.milanese@unisalento.it (M.M.); \\ arturo.derisi@unisalento.it (A.d.R.) \\ * Correspondence: gianpiero.colangelo@unisalento.it; Tel.: +39-0832299440
}

Citation: Colangelo, G.; Raho, B.; Milanese, M.; de Risi, A. Numerical Evaluation of a HVAC System Based on a High-Performance Heat Transfer Fluid. Energies 2021, 14, 3298. https://doi.org/10.3390/en14113298

Academic Editor: Chi-Ming Lai

Received: 21 April 2021

Accepted: 31 May 2021

Published: 4 June 2021

Publisher's Note: MDPI stays neutral with regard to jurisdictional claims in published maps and institutional affiliations.

Copyright: (c) 2021 by the authors. Licensee MDPI, Basel, Switzerland. This article is an open access article distributed under the terms and conditions of the Creative Commons Attribution (CC BY) license (https:// creativecommons.org/licenses/by/ $4.0 /)$.

\begin{abstract}
Nanofluids have great potential to improve the heat transfer properties of liquids, as demonstrated by recent studies. This paper presents a novel idea of utilizing nanofluid. It analyzes the performance of a HVAC (Heating Ventilation Air Conditioning) system using a high-performance heat transfer fluid (water-glycol nanofluid with nanoparticles of $\mathrm{Al}_{2} \mathrm{O}_{3}$ ), in the university campus of Lecce, Italy. The work describes the dynamic model of the building and its heating and cooling system, realized through the simulation software TRNSYS 17. The use of heat transfer fluid inseminated by nanoparticles in a real HVAC system is an innovative application that is difficult to find in the scientific literature so far. This work focuses on comparing the efficiency of the system working with a traditional water-glycol mixture with the same system that use $\mathrm{Al}_{2} \mathrm{O}_{3}$-nanofluid. The results obtained by means of the dynamic simulations have confirmed what theoretically assumed, indicating the working conditions of the HVAC system that lead to lower operating costs and higher COP and EER, guaranteeing the optimal conditions of thermo-hygrometric comfort inside the building. Finally, the results showed that the use of a nanofluid based on water-glycol mixture and alumina increases the efficiency about $10 \%$ and at the same time reduces the electrical energy consumption of the HVAC system.
\end{abstract}

Keywords: nanofluid; thermal conductivity; nanoparticles; TRNSYS; HVAC system; COP

\section{Introduction}

Nanofluids represent a new generation of heat transfer fluids for various applications because of their good thermal performance. They are dilute suspensions of nanometersized particles or fibers dispersed in a liquid. The story of this heat transfer fluids started in 1873 when Maxwell was the first one to carry out studies aimed to increasing the thermal conductivity of liquids through solid particles. Only after more than a century, Choi et al. [1] showed that the addition of metallic nanoparticles increased the thermal conductivity of base-fluids. The use of nanoparticles as additive in heat transfer fluids is preferable to microparticles because they remain in suspension for longer and have a specific surface greater than about a factor of $10^{3}[2,3]$.

Nanofluid's thermal conductivity is a function of several parameters as nanoparticle's material, volume fraction, spatial distribution, size and shape, as well as base fluid type, temperature and Ph. [4-7]. Experimental results generally show an enhancement in thermal conductivity, which increases with the nanoparticle's volume concentration [4]. Das et al. [8] experimentally identified the relationship between thermal conductivity and temperature for nanofluids based on $\mathrm{Al}_{2} \mathrm{O}_{3}$ and with a volume concentration of $1 \%$, that yielded an increase of $2 \%$ in thermal conductivity compared to pure water. Hamilton and Crosser [9] investigated spherical and non-spherical millimeter sized particle suspensions and demonstrated that the shape of the dispersed particles could also play an important role in the determination of the effective thermal conductivity of suspensions. Das [8], Patel [10] and Chon [11] showed the inverse dependence of particle's size on thermal 
conductivity. In particular, Beck et al. [12] reported that thermal conductivity increases with the decrease of nanoparticle's diameter.

One of the main problems related to the use of nanofluids is the nanoparticles stability in suspension. Having a reduced size, they could deposit inside the pipes if not well stabilized and could clog microchannels or erode them superficially, causing pressure drops and other damages in ducts. The stability of any nanofluid is a very significant factor that determines whether the nanofluid is suitable or not for a specific application [13-15]. Stability of nanofluid is strongly affected by the characteristics of suspended particles and base-fluids such as the particles' morphology and their chemical structure. Moreover, due to very high surface to volume ratio, within nanofluids the surface tension between nanoparticles can produce aggregation and sedimentation phenomena. For this reason, the addition of surfactant can improve the stability of the suspension [16,17]. Besides, nanofluids with and without surfactants show a non-Newtonian behavior and their viscosity rises with increasing cluster's size.

Numerical and experimental studies on nanofluids and their applications, such as solar thermal, photovoltaic, internal combustion engines and oil recovery [18], confirmed an increase in heat transfer performance of about $10 \%$ compared to traditional heat transfer fluids, such as water or water-glycol mixtures [19-25]. Even if a small quantity of nanoparticles is added at a volume ratio of less than $1 \%$, the thermal conductivity increases of about $10 \%$ compared to traditional heat transfer fluids, such as water or water-glycol mixtures while the energy efficiency of PVT systems using $\mathrm{SiO}_{2}$-water nanofluids at 1 and $3 \%$ in volume ratio concentration was increased by $3.6 \%$ and $7.9 \%$ respectively, compared to pure water. [25,26]. Reddy et al. [27] and Sardarabadi et al. [28,29] have analyzed nanofluid as refrigerant, flowing in the receiver tube of a linear concentration solar system. In their studies they noted that the addition of nanoparticles in water or oils improved both heat transfer and absorption characteristics of the working fluid. Zheng et al. [30] studied nanofluid as refrigerant fluid in diesel cylinder-head with jet impingement and the computational fluid dynamic simulation demonstrated that the nanofluid had better cooling effect than traditional coolant, but the good effect depended also by the volume fraction of nanofluid. Nanofluids have also been studied as an external cooling jacket around the condenser of an air conditioning system [31]. The experimental results showed that the $\mathrm{Cu}$ and $\mathrm{Al}_{2} \mathrm{O}_{3}$ based nanofluids had a higher temperature-drop than pure water. Moreover, the temperaturedrop increased as the volume fraction of nanoparticles in the liquid increased and this was due to Brownian motion and the thermal properties of nanofluids. Colangelo et al. [32] studied the use of a nanofluid as working fluid in a solar cooling system consisting of several flat solar collectors that supply the generator of a water-lithium bromide absorption chiller. The analysis, carried out by means of the dynamic simulation software TRNSYS, suggested the possibility to use nanofluids in several systems, characterized by closed loop working fluids, in order to improve their efficiency, which means energy and cost savings. Nanofluids consisting of base fluid and carbon nanotubes as cooling liquids were investigated as well [33]. These studies showed a maximum effective efficiency of $42 \%$ compared to pure water because the carbon nanotubes increase the rate of heat transfer. Khullar and Tyagi $[34,35]$ analyzed nanofluid as working fluid in linear parabolic collectors. In particular, they compared the performance of a conventional parabolic collector with a nanofluid-based collector and also studied the effect of various parameters, such as particle concentration ratio and fluid velocity. They found that, under similar working conditions, the linear parabolic collector based on nanofluid was more performing than the conventional one. Marefati et al. [36] have studied the energy and exergetic contribution of the nanofluids in solar collector. They implemented the solar collectors on MATLAB and then have carried out an energy analysis comparing also the cost of electricity of the collectors that use $\mathrm{Cu}$ and $\mathrm{Al}_{2} \mathrm{O}_{3}$ nanoparticles arriving at the solution that aluminum particles lead to a lower electricity cost than $\mathrm{Cu}$. More studies proposed pure carbon-based nanofluid or metal oxides to maximize the solar absorption over a broader solar spectrum; Sattar at al. [37] studied the performance of a direct absorption collector for solar thermal 
energy conversion and their work led to the conclusion that pure graphene oxide based nanofluid is a good potential candidate for direct absorption solar collection to be used in different solar thermal energy conversion applications.

The nanofluid used in this paper is composed by water-glycol and aluminum oxide $\left(\mathrm{Al}_{2} \mathrm{O}_{3}\right)$ nanoparticles, having polycrystalline structure and good mechanical properties, such as resistance to corrosion, abrasion and heat, that deliver efficient, reliable and consistent performance over a wide temperature range with little effects on viscosity, and therefore, on system fluid pumping energy. The use of fluids containing suspended solid particles in HVAC systems are expected to show significant enhancements compared to conventional heat transfer fluids [38]. Balla et al. [39] studied the heat transfer coefficient of multi-metallic nanofluid with $\mathrm{Cu}$ and $\mathrm{Zn}$ nanoparticles. They found that the thermal conductivity of the nanofluid was highly affected by the volume fraction of nanoparticles in particular, the increase was $40 \%$ for $\mathrm{Cu}$ while for the $\mathrm{Zn}$ it was $20 \%$ compared to water for volume fraction of $1 \%$. In the studies carried out so far, $\mathrm{Al}_{2} \mathrm{O}_{3}$-water mixture has an increase in viscosity between $20 \%$ and $30 \%$ for $3 \% \mathrm{vol} \mathrm{Al}_{2} \mathrm{O}_{3}$ [40]. In particular, the viscosity of the $\mathrm{Al}_{2} \mathrm{O}_{3}$-ethylene glycol solution has a similar viscosity of $\mathrm{Al}_{2} \mathrm{O}_{3}$-water, but the first one has a higher thermal conductivity than the second one. Jasim et al. [41] studied the improvement in thermal performance of $\mathrm{Al}_{2} \mathrm{O}_{3}$-water nanofluid in a double pipe heat exchanger and their results indicated that the heat transfer increased with increasing nanofluid volume concentration and volume flow rates. Das et al. [42] observed that the use of nanofluids in heating of buildings can reduce the size of the heat transfer system, with positive effects on pressure drops and subsequent pumping power; besides nanofluids can reduce also the size of heat exchangers, pumps and other components.

The objective of this work was to calculate the increase in performance of a HVAC system, due to the use of a nanofluid, evaluating all energy fluxes, in order to prepare the field for an extended experimental campaign. TRNSYS has been used to study, analyze and quantify the efficiency of the system and to evaluate its transient and average performance [43].

\section{TRNSYS Model}

In this work an educational building was simulated by using the dynamic software TRNSYS 17. This is a software used to simulate the behavior of transient systems [44-46], having the capability of interconnecting system components, solving the system differential equations and producing useful information as output. It allows the modelling of the building components including the occupancy profile, internal and external gains, orientation and solar gains through windows, longwave radiation exchange with other walls and windows, HVAC systems etc. It is also possible to represent the real stratigraphy of the building's wall elements.

The building considered in this paper (Figure 1), was built in 2001 and it is located in Monteroni of Lecce, a small town in the South of Italy (Lat. $40^{\circ} 19^{\prime}$, Long. $18^{\circ} 5^{\prime}$ ).

According to the Italian regulations UNI 10349-1:2016, Lecce is located in the climatic zone $C$ and the standard heating season ranges from 15 November to 30 March. 


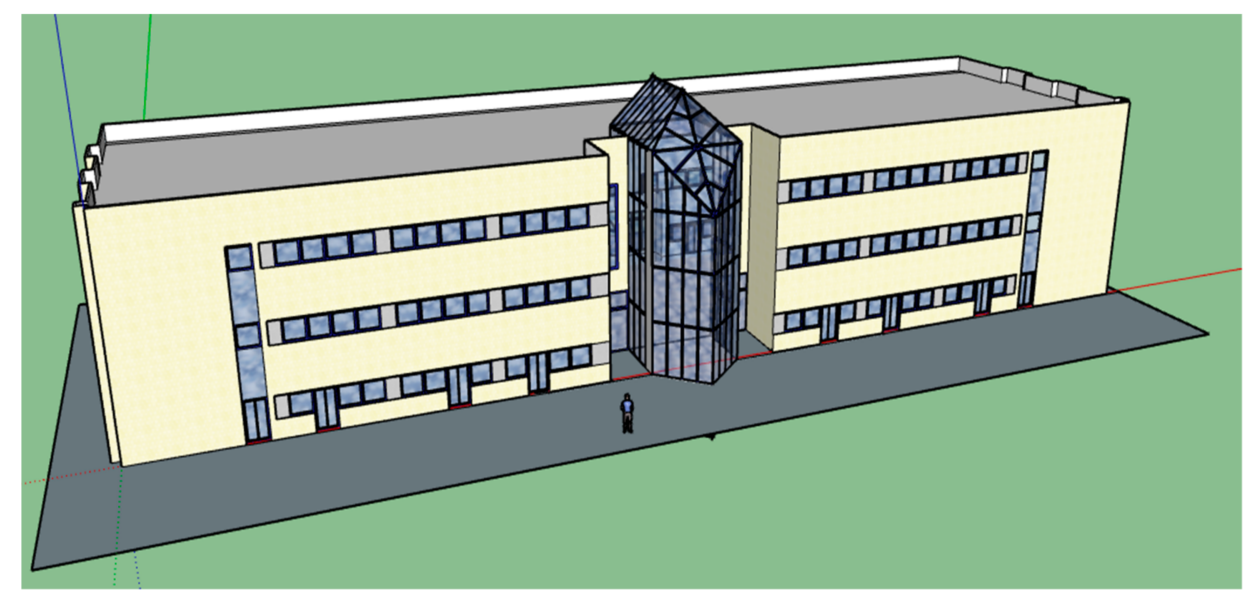

Figure 1. 3D view of the educational building "Corpo $\mathrm{O}$ " in the Campus of University of Salento, Lecce, Italy.

\subsection{Building Description}

The educational building under investigation is characterized by a symmetry that divides it into 2 mirror parts, equipped with the same HVAC system. The structure consists of four floors, three of them are air conditioned, while the basement floor is an unconditioned zone.

The building was simulated as a multizone building by means of the TRNBUILD plug-in. Particularly, the building model was developed by considering six typologies of thermal zones:
1. right ground floor;
2. left ground floor;
3. right first floor;
4. left first floor;
5. right second floor;
6. left second floor.

The infiltration rate was set equal to 0.5 changes per hour, according to the UNI 12831-2006, while the internal gains, related to video terminals, computers, copiers, server, printers, etc., have been modeled with the convective fraction of 0.4 , as defined by the ISO 52016-1:2017 and considering the following occupancy profile: 8.00-18.00 from Monday to Friday for students, while for teachers and school staff 8.00-14.00 during Saturday as well. Room lighting was provided by fluorescent lamps when the natural light was not sufficient. Finally, each zone was characterized by an indoor ambient temperature equal to $20^{\circ} \mathrm{C}$ in winter and $26^{\circ} \mathrm{C}$ in summer, according to the UNI 10344.

In the present analysis 4 different opaque elements and 2 transparent windows were considered, whose main thermophysical characteristics are reported in Tables 1 and 2 respectively. In particular, the windows have been chosen from the TRNSYS library so that the specified thermal transmittance values correspond to the values for the reference building in Italy. 
Table 1. Thermophysical properties of opaque components of the building.

\begin{tabular}{|c|c|c|c|c|c|c|c|}
\hline LAYER & $\begin{array}{c}S \\
{[\mathrm{~m}]}\end{array}$ & $\begin{array}{c}\lambda \\
{\left[W / m^{\circ} \mathrm{C}\right]}\end{array}$ & $\begin{array}{c}\mathrm{C} \\
{\left[\mathrm{W} / \mathrm{m}^{\circ} \mathrm{C}\right]}\end{array}$ & $\rho\left[\mathrm{kg} / \mathrm{m}^{3}\right]$ & $\begin{array}{c}\delta_{\mathrm{a}} \times 10^{12} \\
{[\mathrm{~kg} \mathrm{~m} \mathrm{~s} \mathrm{~Pa}]}\end{array}$ & $\begin{array}{c}\delta_{\mathrm{u}} \times 10^{12} \\
{[\mathrm{~kg} \mathrm{~m} \mathrm{~s} \mathrm{~Pa}]}\end{array}$ & $\begin{array}{c}\mathbf{R} \\
{\left[\mathbf{m}^{\circ} \mathrm{C} / \mathrm{W}\right]}\end{array}$ \\
\hline \multicolumn{8}{|c|}{ EXTERNAL WALL } \\
\hline Tuff & 0.1 & 1.7 & & 2300 & 0.019 & 0.021 & 0.059 \\
\hline Air gap 100 mm & 0.1 & 0.64 & & 1 & 193 & 212.3 & 0.156 \\
\hline Polyurethane foam & 0.05 & 0.04 & & 30 & 2.412 & 2.654 & 1.25 \\
\hline Tuff & 0.15 & 0.63 & 4200 & 1400 & 0.019 & 0.021 & 0.238 \\
\hline Lime plaster & 0.01 & 0.7 & 35 & 1400 & 19.3 & 21.23 & 0.014 \\
\hline \multicolumn{8}{|c|}{ INTERNAL WALL } \\
\hline Lime plaster & 0.01 & 0.7 & 35 & 1400 & 19.3 & 21.23 & 0.014 \\
\hline Perforated brick 1.1.22 150 & 0.15 & & 2.22 & 1800 & 193 & 212.3 & 0.45 \\
\hline Lime plaster & 0.01 & 0.7 & 35 & 1400 & 19.3 & 21.23 & 0.014 \\
\hline \multicolumn{8}{|c|}{ INTERNAL FLOOR } \\
\hline Marble tiles & 0.02 & 3 & 300 & 2700 & 0.019 & 0.021 & 0.007 \\
\hline Ordinary concrete & 0.1 & 1.28 & & 2200 & 2.757 & 3.033 & 0.078 \\
\hline Dry sand & 0.02 & 0.6 & & 1700 & 12.867 & 14.153 & 0.033 \\
\hline Floor block 2.1.031/1 180 & 0.25 & & 3.33 & 1800 & 193 & 212.3 & 0.3 \\
\hline Lime or cement mortar & 0.01 & 0.9 & & 1800 & 9.65 & 10.615 & 0.011 \\
\hline \multicolumn{8}{|c|}{ COVERING ROOF } \\
\hline Ordinary concrete & 0.02 & 1.28 & & 2200 & 2.757 & 3.033 & 0.016 \\
\hline Exterior brick wall 800 & 0.13 & 0.41 & & 800 & 38.6 & 42.46 & 0.317 \\
\hline Ordinary concrete & 0.04 & 1.28 & & 2200 & 2.757 & 3.033 & 0.031 \\
\hline Synthetic foamed polyester & 0.02 & 0.04 & & 20 & 4.289 & 4.718 & 0.5 \\
\hline Ext. wall reinforced concrete & 0.13 & 1.31 & & 2000 & 3.86 & 4.246 & 0.099 \\
\hline Semi-rigid wood panel & 0.02 & 0.043 & & 20 & 193 & 212.3 & 0.465 \\
\hline Lime or cement mortar & 0.02 & 0.9 & & 180 & 9.65 & 10.615 & 0.022 \\
\hline Terracotta tiles & 0.02 & 0.72 & & 1800 & 27.571 & 30.329 & 0.028 \\
\hline
\end{tabular}

Table 2. Thermophysical properties of the windows.

\begin{tabular}{|c|c|c|c|c|c|c|c|}
\hline Description & $\begin{array}{c}A_{g} \\
{\left[\mathrm{~m}^{2}\right]}\end{array}$ & $\begin{array}{c}A_{f} \\
{\left[m^{2}\right]}\end{array}$ & $\begin{array}{c}\mathrm{Lg}_{\mathrm{g}} \\
{[\mathrm{m}]}\end{array}$ & $\begin{array}{c}\mathrm{K}_{\mathrm{g}} \\
{\left[\mathrm{W} / \mathrm{m}^{2 \circ} \mathrm{C}\right]}\end{array}$ & $\underset{\left[W / m^{2 \circ} \mathrm{C}\right]}{K_{f}}$ & $\begin{array}{c}\mathrm{K}_{1} \\
{\left[\mathrm{~W} / \mathrm{m}^{2 \circ} \mathrm{C}\right]}\end{array}$ & $\begin{array}{c}\mathrm{K}_{\mathrm{W}} \\
{\left[\mathrm{W} / \mathrm{m}^{2}{ }^{2} \mathrm{C}\right]}\end{array}$ \\
\hline \multicolumn{8}{|c|}{ WINDOW } \\
\hline Single window & 1.35 & 0.09 & 4.6 & 1.045 & 3 & & 1.173 \\
\hline \multicolumn{8}{|c|}{ WINDOW GLASS } \\
\hline Single window & 1.79 & 0.45 & 5.28 & 1.045 & 3 & & 1.442 \\
\hline
\end{tabular}

Actually, each HVAC system is composed by two heat pumps and AHU (Air Handling Unit). The characteristics of these components are shown in Tables 3 and 4. 
Table 3. Air Handling Unit characteristics.

\begin{tabular}{lc}
\hline Model & Air Handling Unit UTS 05 \\
\hline Air flow & $6000 \mathrm{~m}^{3} / \mathrm{h}$ \\
Static pressure & $200 \mathrm{~Pa}$ \\
Absorbed power & $0.55 \mathrm{~kW}$ \\
\hline Cold coil with chilled water & \\
\hline Water flow & $11.8 \mathrm{~m}^{3} / \mathrm{h}$ \\
Air Temperature & $\mathrm{In} 32^{\circ} \mathrm{C}$ \\
& $\mathrm{Out} 13.6^{\circ} \mathrm{C}$ \\
Pressure drop & $169 \mathrm{~Pa}$ \\
Flow speed & $2.5 \mathrm{~m} / \mathrm{s}$ \\
Water Temperature & $\mathrm{In} 7{ }^{\circ} \mathrm{C}$ \\
Pressure drop & $\mathrm{Out} 12{ }^{\circ} \mathrm{C}$ \\
\hline Cross flow heat recovery unit with upper shutters & $26.5 \mathrm{kPa}$ \\
\hline Supply air flow & \\
Supply air temperature & $6000 \mathrm{~m}^{3} / \mathrm{h}$ \\
Extract air flow & $-5{ }^{\circ} \mathrm{C}$ \\
Extract air temperature & $5000 \mathrm{~m}^{3} / \mathrm{h}$ \\
Fresh air temperature & $22^{\circ} \mathrm{C}$ \\
Total efficiency & $8{ }^{\circ} \mathrm{C}$ \\
\hline
\end{tabular}

Table 4. Heat pump characteristics.

\begin{tabular}{lc}
\hline \multicolumn{1}{c}{ Model } & WSAN-XEE 302 \\
\hline $\begin{array}{l}\text { Compressor } \\
\text { Type }\end{array}$ & 2 Scroll \\
Refrigerant circuit & 1 \\
Refrigerant charge & $8.28 \mathrm{~L}$ \\
Internal exchanger & \\
Water flow & $3.4 \mathrm{~L} / \mathrm{s}$ \\
Maximum water flow & $5.4 \mathrm{~L} / \mathrm{s}$ \\
Pressure decrease & $41.9 \mathrm{kPa}$ \\
Useful pump discharge & $131 \mathrm{kPa}$ \\
External exchanger & \\
Fans & 6 \\
Standard air flow & \\
Installed power unit & $6971 \mathrm{~L} / \mathrm{s}$ \\
Expansion case & $0.18 \mathrm{~kW}$ \\
Capacity & \\
Maximum pressure on the water & $5 \mathrm{~L}$ \\
Storage tank & $550 \mathrm{kPa}$ \\
Inertial tank & \\
\hline
\end{tabular}

\subsection{Simulation Model}

The building was simulated by using a time step of $1 \mathrm{~h}$ and by considering the heating and cooling season as simulation duration. Particularly, the HVAC system of the educational building was modelled in TRNSYS, as shown in Figure 2. 


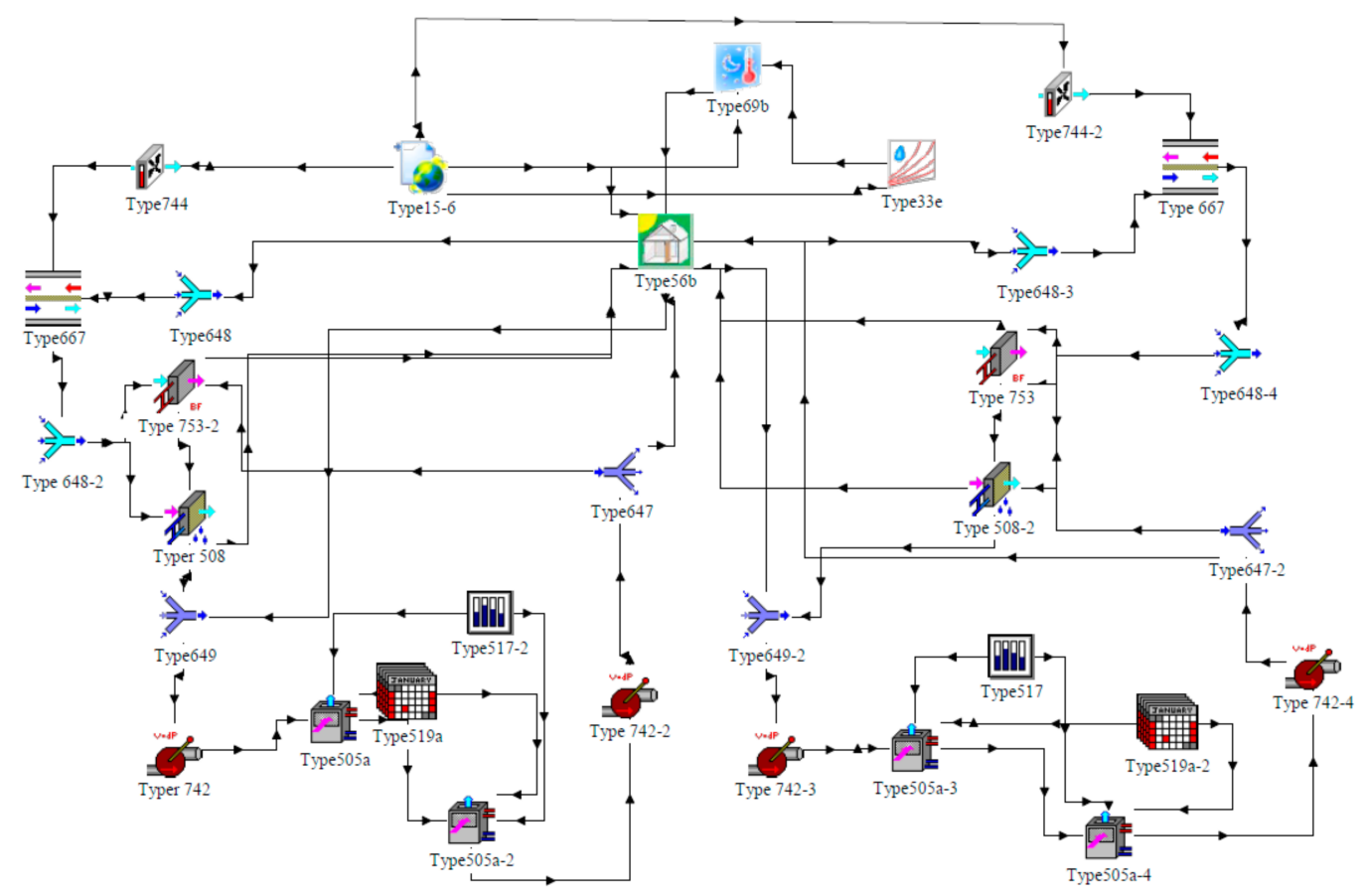

Figure 2. System model in TRNSYS.

TRNSYS 17 allows analyzing the system in a semi-dynamic way, having the advantage of working with the typical weather data of the region, in order to study the system under more realistic operating conditions [47]: the typical meteorological year (TMY) that represents the climate of Lecce, included within TRNSYS weather data files, was employed as climatic input data.

With reference to Figure 2, for each side of the building, the air is extracted from the outside through a fan (Type 744), passes through the heat pumps (Type 505) (arranged in parallel configuration), where the heat transfer between air and fluid takes place. By a distribution system (Type 647), the air passes through the heating or cooling batteries (Type 753 and 508 respectively) and finally it arrives in the building (Type 56), satisfying the required thermal loads. The structure is equipped with an air recirculation system that allows to extract from the indoor environment, by means of fans, about $5000 \mathrm{~m}^{3} / \mathrm{h}$ of exhaust air and send it to a crossflow static recovery heat exchanger (Type 667). In this component, $5000 \mathrm{~m}^{3} / \mathrm{h}$ of exhaust air exchanges heat with $6000 \mathrm{~m}^{3} / \mathrm{h}$ of external fresh air, which, once regenerated, enters within the air handling unit and then circulates in the HVAC circuit. The remaining air, on the other hand, is expelled to the outside environment.

On the water side, the system is a closed loop circuit. The water coming out from the heat pumps fed the fan coil units inside the building and the coil of the AHU through the circulation pumps (Type 742). After the heat exchange, the water from the utilities returns to the heat pumps to start a new cycle.

Type 56 models the thermal behavior of the building, whose characteristics are stored in a set of external files, obtained by running the preprocessor program TRNBuild. It calculates inside air temperatures, ventilation rates, infiltration etc., according to the thermal characteristics of the building $[44,48,49]$.

Type 505 models a single-stage liquid source heat pump. This component conditions the main air stream by rejecting energy to (cooling mode) or absorbing energy from (heating mode) a liquid flow. Type 505 is based on user-supplied data files containing catalog data for the capacity (both total and sensible in cooling mode), and power, based on the entering water temperature to the heat pump, the entering water flow rate and the air flow rate.

The power-on of the heat pumps is scheduled according to technical standards. Since it is located in climatic zone C, the system operates from 15 November to 30 March in 
heating mode and from 15 June to 15 September in cooling mode. This on-off program is controlled by a heating and cooling season scheduler (Type 517 and Type 519).

Type 753 and Type 508 model a simple heating and cooling coil, respectively where the air is heated or cooled as it passes across a coil containing a hotter or cooler fluid (typically water-glycol). This model uses the bypass fraction approach for heating and cooling coil to solve the outlet air and water conditions.

Within the TRNSYS types, the nanofluid is considered as a continuous, homogeneous, single-phase fluid and only the macroscopic thermophysical properties are considered.

\subsection{Second Simulation Model}

Using different heat transfer fluids involves the variation of the overall heat exchange coefficient of the system, because it depends on the convective heat transfer coefficient as the different chemical and physics composition of the heat transfer fluid leads to a variation of the thermo-physical properties.

By analogy with the Ohm's law, the global heat transfer coefficient of the system (U) is related to the total thermal resistance $R_{t}$ by the following Equation (1):

$$
\mathrm{R}_{\mathrm{t}}=\frac{1}{\mathrm{UA}}
$$

The external convective heat transfer coefficient $h_{e}$ is $10 \div 100 \mathrm{~W} / \mathrm{m}^{3} \mathrm{~K}$, but the internal convective heat exchange coefficient is different, according to the different types of heat transfer fluids used, because it depends on the Nusselt number $(\mathrm{Nu})[50]$ and on thermal conductivity of the fluid $\left(\mathrm{k}_{\mathrm{p}}\right)$, according to Equation (2):

$$
\mathrm{h}_{\mathrm{i}}=\frac{\mathrm{Nuk}_{\mathrm{p}}}{\mathrm{D}}
$$

In order to take into account, the increase in the convective heat transfer coefficient, it was decided to carry out a simulation that presents a different model of the HVAC system. In this model, represented in Figure 3, an external heat exchanger has been added (represented by Type 17), because the heat pump represented by type 505 does not consider the different convective heat transfer coefficient of the nanofluid, but only the specific heat capacity of the heat transfer fluid, therefore an external heat exchanger was used in such a way, to consider the global heat transfer coefficient (UA) as input data for the energy calculations in a more accurate and realistic way.

The heat transfer fluid coming out of the heat pumps is conducted into an external heat exchanger, represented by type 17, optimized to exploit the improved heat transfer performance of the nanofluid. This element takes into account the change in the overall heat exchange transmittance (UA) and the specific heat of the heat transfer fluid and calculates the efficiency for a given fixed value of the overall heat transfer coefficient. Of course, the change in the heat transfer fluid leads to a change in the overall heat transfer conductance because it depends on the chemical and physical characteristics of the working fluid used in the system. 


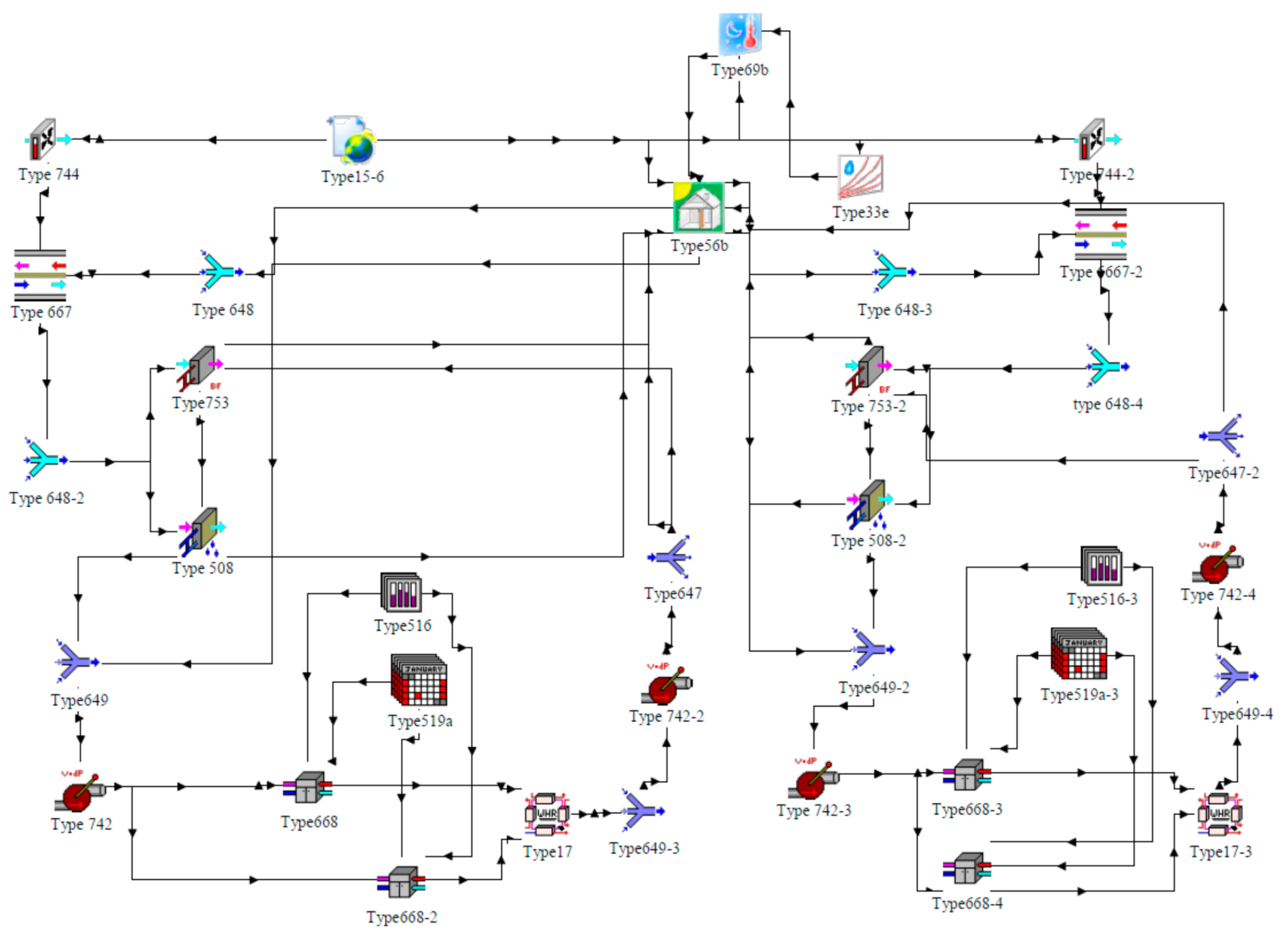

Figure 3. Second system model with ad-hoc external exchanger in TRNSYS.

In this new system, represented by the scheme in Figure 3, the heat pump's parameters in input are the macroscopic properties of the nanofluid such as thermal conductivity, specific heat, viscosity and density.

In particular the heat pump simulated by type 668 operates in temperature level control like an actual heat pump would. This type takes the density, the specific heat and inlet flow temperature of liquid stream as input parameters. The absorbed energy from the heat transfer fluid in heating is given by the Equation (3):

$$
\dot{Q}_{\text {absorbed } / \text { rejected }}=\text { Capheating/cooling } \mp \dot{P}_{\text {heating } / \text { cooling }}
$$

where Capheating/cooling is the machine's heating/cooling and $\dot{P}_{\text {heating/cooling }}$ is the power draw.

The outlet temperatures of the liquid streams can then be calculated using Equation (4):

$$
T_{\text {source,out }}=T_{\text {source, } \text {, }} \mp \frac{\dot{Q}_{\text {absorbed } / \text { rejected }}}{\dot{m}_{\text {source }} C p_{\text {source }}}
$$

The heat pumps, represented by the type 668 or 505 , do not consider the different heat transfer coefficient $h$ of the nanofluid, therefore it was thought to simulate the external heat exchanger using the type 17 which represents an external heat exchanger.

In particular, with the external exchanger it is possible to consider the importance of heat exchanger transmittance of the nanofluid because this type takes mass flow rate and the overall conductance for heat exchanger as input parameters. Type 17 relies on an effectiveness minimum capacitance approach to model the heat exchanger. The type needs as input the heat exchanger's UA and inlet conditions. The model then calculates whether the cold or the hot side is the minimum capacitance (Equations (5) and (6)) side 
and then calculates the effectiveness based upon the specified flow configuration and on UA by Equation (7):

$$
\begin{gathered}
C_{\text {cooling }}=\dot{m}_{C} C_{p c} \\
C_{\text {heating }}=\dot{m}_{h} C_{p h} \\
\varepsilon=1-\exp \left[\left(\frac{C_{\text {min }}}{C_{\text {max }}}\right)\left(\frac{U A}{C_{\text {min }}}\right)^{0.22}\left\{\exp \left[\left(\frac{-C_{\min }}{C_{\text {max }}}\right)\left(\frac{U A}{C_{\text {min }}}\right)^{0.78}\right]-1\right\}\right]
\end{gathered}
$$

The type 17 takes into account the increase in the heat exchanger coefficient of the nanofluid and the changes in energy performance of the entire system.

\subsection{Nanofluid Characteristics}

In order to calculate the increase in performance of the HVAC system, due to the use of a nanofluid as heat transfer fluid, in this study an aluminum oxide-based nanofluid, Maxwell2020 [51], has been considered. It is capable of increasing thermal conductivity and convective heat transfer with respect to the base fluid. Its characteristics are summarized

\begin{tabular}{|c|c|}
\hline \multicolumn{2}{|l|}{ Composition (\% by Weight) } \\
\hline Propylene Glycol & 37 \\
\hline Performance Additives & 2 \\
\hline Water & 61 \\
\hline Color & White \\
\hline Odor & Odorless \\
\hline pH & 10 \\
\hline Specific Weight $\left[\mathrm{kg} / \mathrm{m}^{3}\right]$ at $25^{\circ} \mathrm{C}$ & 1.078 \\
\hline Operating Range $\left[{ }^{\circ} \mathrm{C}\right]$ & -22 to 65 \\
\hline Freeze Point $\left[{ }^{\circ} \mathrm{C}\right]$ & -22 \\
\hline Burst Point $\left[{ }^{\circ} \mathrm{C}\right]$ & -51 \\
\hline Boiling Point $\left[{ }^{\circ} \mathrm{C}\right]$ & 105 \\
\hline Flash Point $\left[{ }^{\circ} \mathrm{C}\right]$ & 104 \\
\hline Thermal Conductivity $[\mathrm{W} / \mathrm{m} \mathrm{K}]$ at $20^{\circ} \mathrm{C}$ & 0.471 \\
\hline Specific Heat $[\mathrm{kJ} / \mathrm{kg} \mathrm{K}]$ at $20^{\circ} \mathrm{C}$ & 3.51 \\
\hline Viscosity [mPa s] at $20^{\circ} \mathrm{C}$ & 4.74 \\
\hline
\end{tabular}
in the Table 5.

Table 5. Properties of the nanofluid, called MAXWELL 2020 [51], used in the simulations.

\section{Model Validation}

An experimental analysis was carried out on the real HVAC system of the building in order to validate the TRNSYS model. The test consists in installing nanofluid in one of the two symmetric units of the HVAC system and comparing their performance one against the other, monitoring the performance of each unit of the HVAC system.

During the experimental analysis the thermal energy produced by each system was monitored by means of thermal energy meters.

The thermal energy meter (CONTECA EASY by Caleffi) is of the direct type and it is particularly suitable for measuring thermal consumptions in civil buildings. It consists of an electronic calculation unit, a turbine volume flow meter and two temperature probes. The technology and the materials used allow a precise and reliable measurement.

The flow meter is made of steel, has a flanged connection, and resists to a fluid temperature of $90^{\circ} \mathrm{C}$. It was installed in horizontal position respecting the flow direction. The temperature probes are of high precision NTC type, with a measurement sensitivity lower than $0.05^{\circ} \mathrm{C}$. They have been positioned in correspondence of the inlet flow and return pipes according to the EU EN 1434 and DIN 40050.

The thermal energy meter is able to acquire up to four pulse inputs, two of which are digital. In the experimental tests a centralized remote transmission in M-Bus was used. 
The acquisition device (Datalogger DATA EASY) allows to acquire and to record the data from the thermal energy meter and has an integrated web interface that allows the analysis of consumptions, instant data and the possibility of consulting historical data up to a maximum of 10 years.

Testing was focused on measuring the coefficient of performance (COP) of both HVAC lines. The coefficient of performance was calculated as:

$$
\mathrm{COP}=\frac{E_{t h}}{E_{e l}},
$$

where $E_{t h}$ is the output thermal energy $(\mathrm{kWh})$ and $E_{e l}$ is the input electrical energy consumption $(\mathrm{kWh})$.

Experimental analysis last fifteen days in the heating season, from the 2 March 2020 to the 12 March 2020. In this phase, both HVAC systems operated under similar conditions. The system operating with nanofluid was "Circuit 1 ", while the other one "Circuit 2 ".

The results of experimental tests were analyzed and showed that Circuit 1 had an increase in performance.

The average increase in performance in the two weeks of testing was $10.8 \%$.

The data acquired by the thermal energy meters were compared with the data obtained by the simulations carried out by means of TRSNSY software. For the simulations it was used the climatic data of Lecce, from 2 March 2020 to the 12 March 2020, from the weather data archive provided by ARPA [52], the regional agency for the environmental protection, that monitors the climatic conditions by means of a weather station located in Lecce.

The system simulated by TRNSYS software works in the same temperature range at the terminals, $45^{\circ} \mathrm{C}$ in the winter as the real one. Both the systems (the simulated one and the real one) are active in the same working hours, from 8 a.m. to 4 p.m. and under the same real weather conditions, provided by the Arpa site [52].

In Figures 4 and 5 it is possible to compare the COP values obtained by the simulations and the results by the experimental tests in CLIVET 1 and CLIVET 2 respectively. From the graphs it can be seen that the COP obtained by the simulations are very similar to the experimental ones, with less than $10 \%$ of error, therefore the TRNSYS model is reliable.

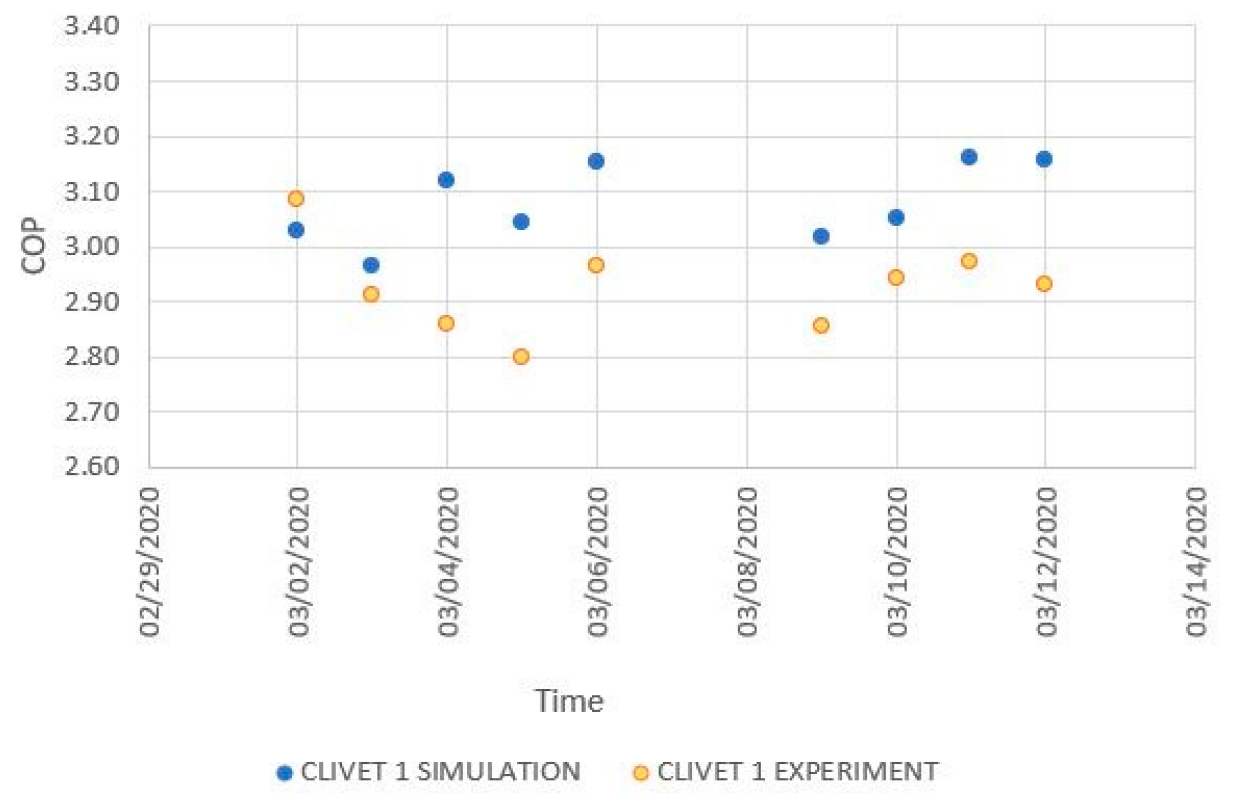

Figure 4. Comparison between COP values by simulation and experiments for CLIVET 1. 


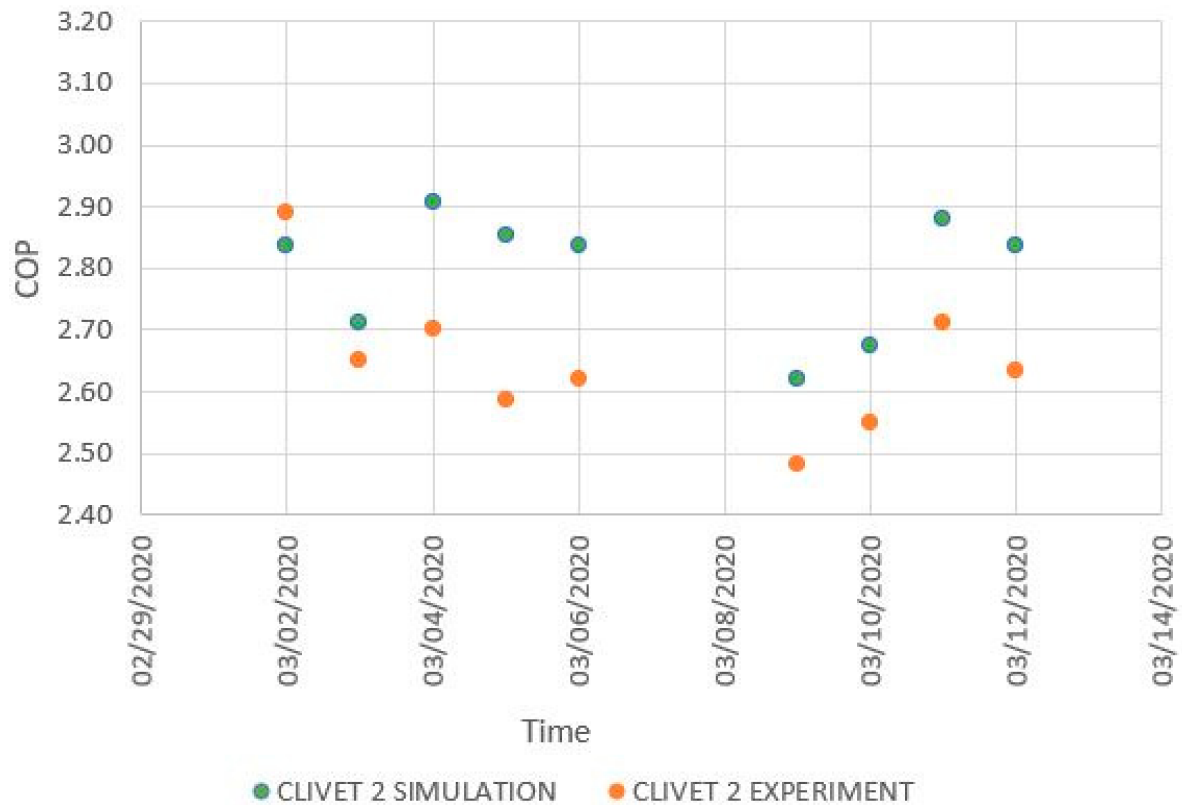

Figure 5. Comparison between COP values by simulation and experiments for CLIVET 2.

\section{Results and Discussion}

The graph in Figure 6 shows the energy request in heating and cooling seasons by the building for a whole year. The building's thermal demand is expressed in $\mathrm{kWh}$ in absolute values.

The total thermal requirement, represented by in Figure 6, includes the sensible and latent heat required by the building during a whole year and can be divided into winter and summer season, represented by red and blue, respectively.

The building's winter thermal loads, which are the ventilation, infiltration, and humidification load, were taken into account, while in summer it was considered the high load due to the radiation to which the building is subjected. For the whole year were considered the internal loads due to lighting, video terminals and the presence of staff inside in the office.

From the Figure 6 it is possible to see areas in which there is no request for thermal load by the building and this is due to the fact in those months, in particular April, May, October and mid-November, the air condition and heating systema are turned off by regulations. 


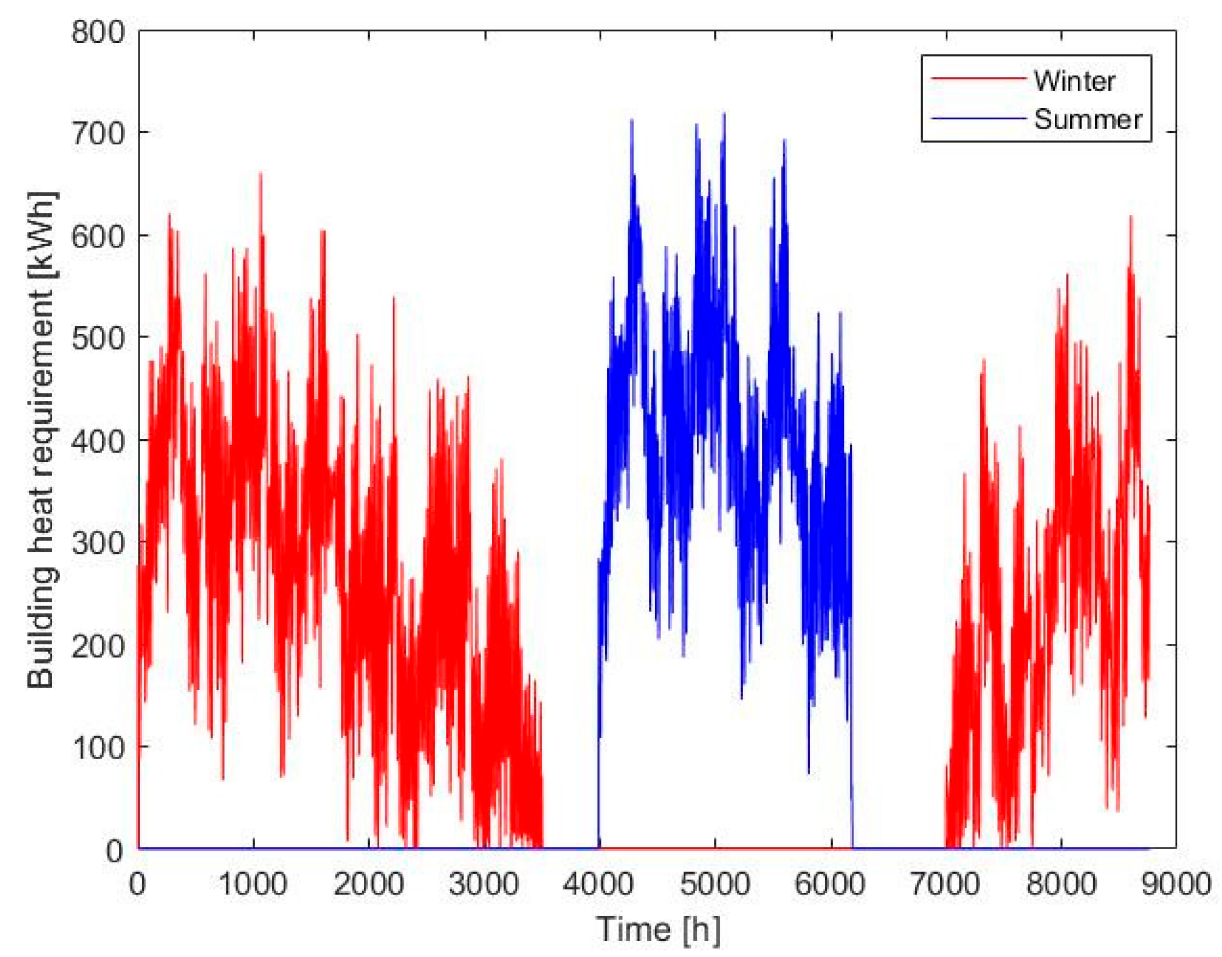

Figure 6. Energy request for "Corpo $\mathrm{O}$ " by dinamic simulation.

The performance of the HVAC system working with water and glycol as heat transfer fluid and the same system working with nanofluid have been compared. Particularly, three different dynamic simulations lasting $8760 \mathrm{~h}$ ( 1 year) were compared by means of TRNSYS with a time step of $1 \mathrm{~h}$ :

- 1st simulation: HVAC system in standard operation (without changes to operating conditions) working with traditional heat transfer fluid (60\% of water and $40 \%$ of glycol) and nanofluid;

- 2nd simulation: HVAC system working by keeping the thermal power transferred to the building constant and using water-glycol first and nanofluid after;

- $\quad 3 r d$ simulation: HVAC system with external heat exchanger working with traditional heat transfer fluid and nanofluid.

\section{Simulations}

In the first simulation, the results show that by using nanofluid and consuming about $2 \%$ more it is possible to obtain an increase in heat transferred to the building of about $8 \%$. In addition, each heat pump shows a higher coefficient of performance with nanofluid than water-glycol of $4.4 \%$ and $2.6 \%$ for COP and EER respectively.

In the second simulation the HVAC system has been simulated keeping constant the thermal power transferred to the building. To obtain this result, the fancoils temperature has been modified: if water-glycol is used as heat transfer fluid, its normal value is equal to $45^{\circ} \mathrm{C}$ and $10^{\circ} \mathrm{C}$ in heating and cooling season, respectively. While, with the nanofluid, it has been set to $40^{\circ} \mathrm{C}$ and $15^{\circ} \mathrm{C}$.

As can be seen in Figure 5, in the third simulation there is a further increase in the performance of the system with nanofluid, compared to that with base fluid, because the third simulation considers the increase in the heat transfer performance of nanofluid.

With the addition of an external heat exchanger in the model in TRNSYS there will be an increase of the transferred heat of $11 \%$ for the system with nanofluid. The system working with nanofluid, however, is able to transfer about $11 \%$ more heat and to consume about $1 \%$ less electricity. 
In this case it is confirmed what was supposed under the theoretical point of view: the nanofluid is more performing than the traditional mixture of water and glycol both under the heat transfer performance and consumption points of view.

Figure 7 shows that in the first simulation the nanofluid system is more performing than the system working with traditional fluid. Actually, in winter and in summer the heat transferred from the nanofluid system is about $10 \%$ more than the heat transferred from the other one. The second simulation is a comparison between the two systems with the same transferred heat, but with a different operating range of the heat pumps, therefore in the Figure 5 the values of heat transferred in the two systems are the same.

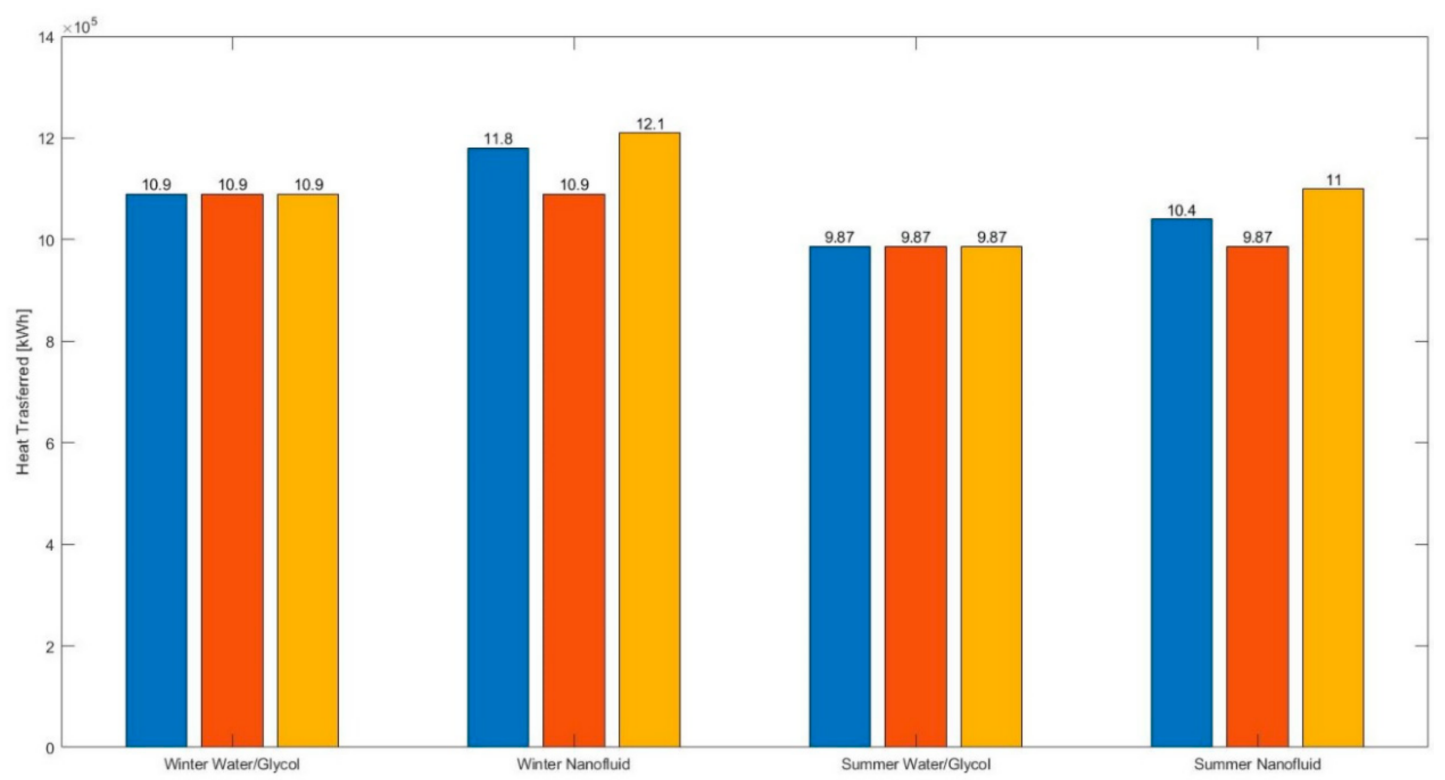

Figure 7. Heat transfer (Energy) for water-glycol and nanofluid in the different seasons.

Further results of the simulations are shown in Figures 8 and 9. Particularly in Figure 6, the first simulation shows that the performance of the nanofluid is higher than that with water-glycol (COP $=4.02$ instead of 3.85 and EER $=3.87$ instead of 3.77). Moreover, an additional increase is obtained in the second simulation with a COP that goes from 4.02 to 4.12 and an EER that increases from 3.87 to 4.00 .

In Figure 8 it is possible to note that the presence of the external heat exchanger does not change the performance of the system in particular, COP and EER coefficient of performance increase further. On the other hand, the COP performance coefficient in the system with nanofluid yields an increase of about $8 \%$ compared to the water and glycol system, with a value of 4.16 , in place of the results found in the other two simulations, which were $4.4 \%$ and $7 \%$ for the first and second simulation respectively. 


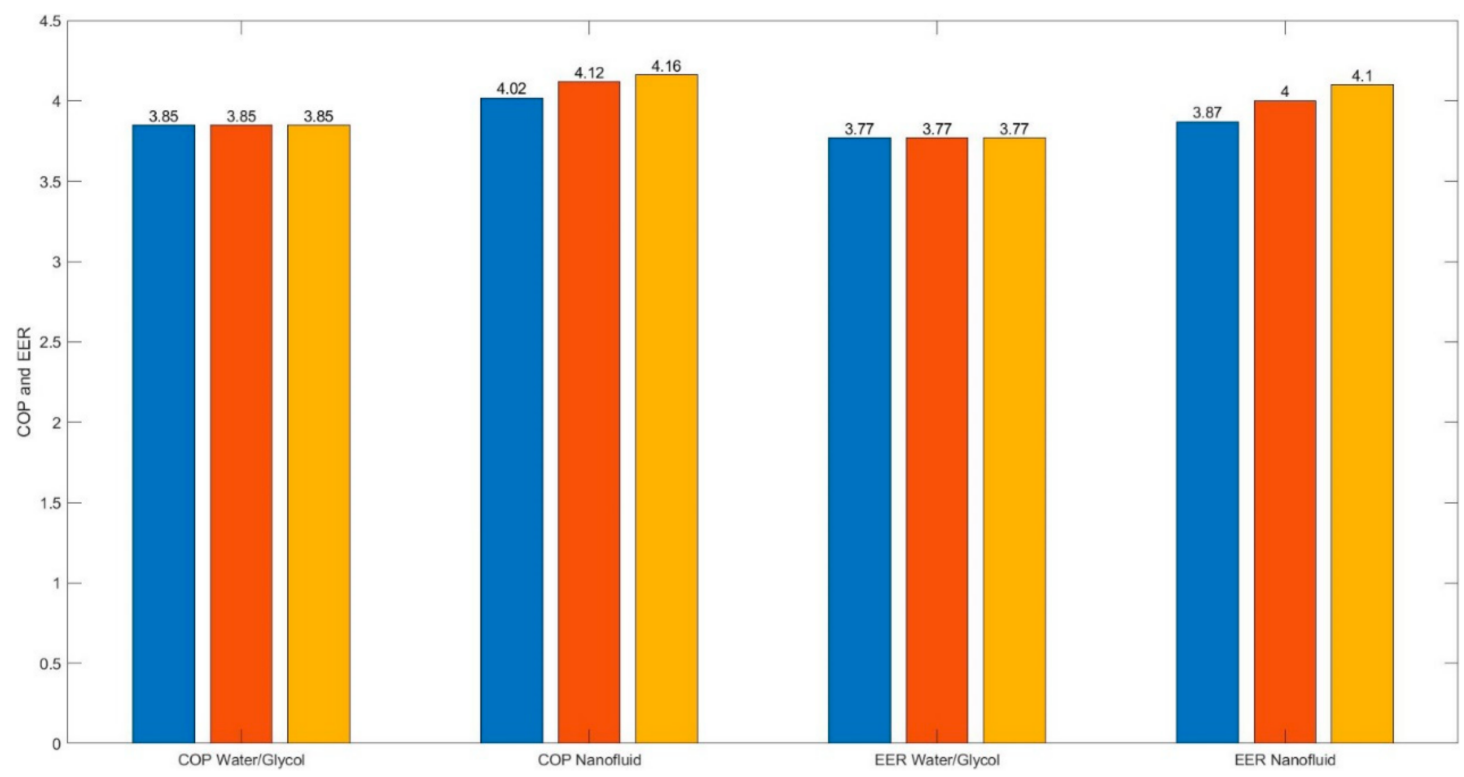

Figure 8. Comparison of the coefficients of performance(COP and EER) of the HVAC systems in winter and in summer in the different simulations.

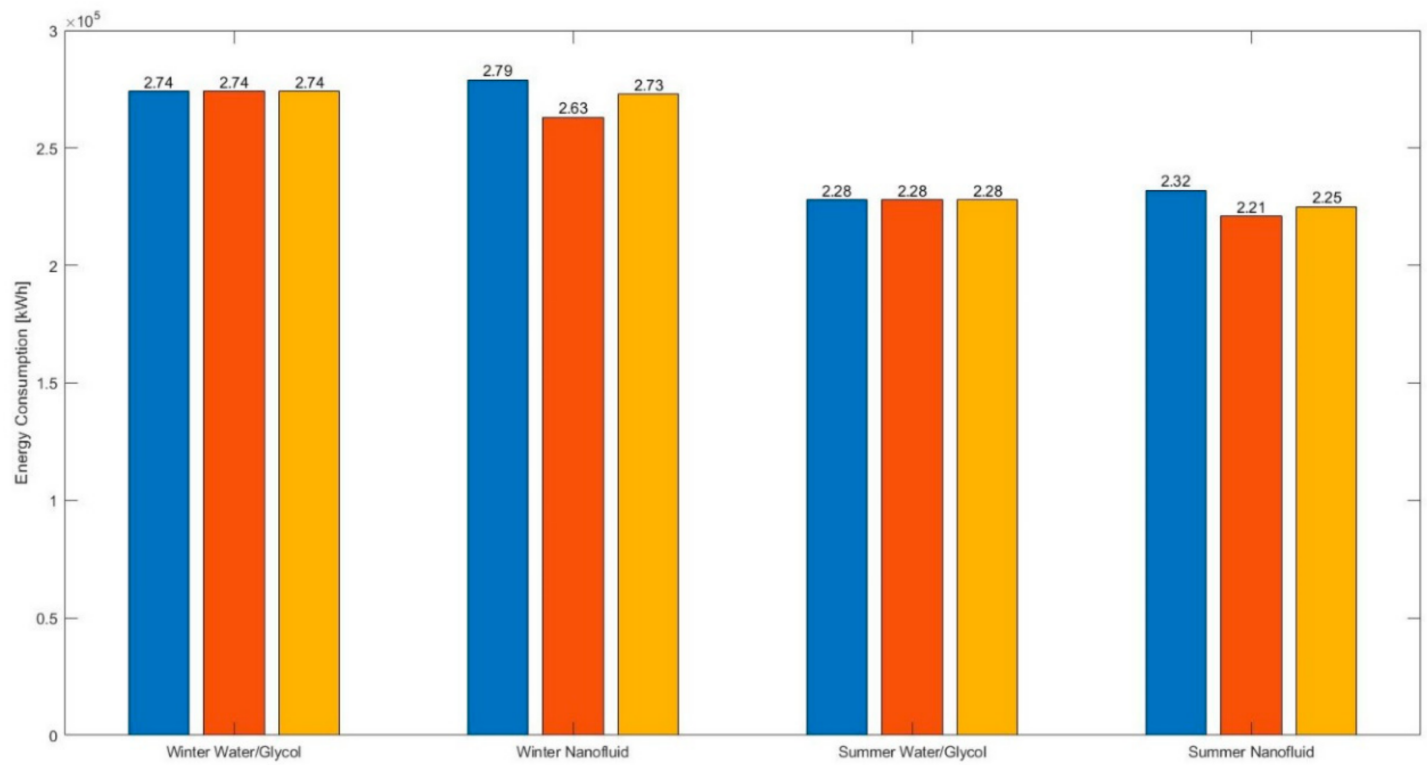

Figure 9. Heat pumps electric energy absorbed in winter and summer in all simulations.

Figure 9 shows the electric energy absorbed by the heat pumps during the whole winter and summer seasons. The graph shows that also in the first simulation the system working with nanofluid has a slightly higher energy consumption than the other one. In the second simulation, on the other hand, the energy consumption decreases further because, with the same amount of heat transferred from the two systems, the circuit with nanofluid has a different temperature range at the terminals. In particular, in winter the outlet temperature of the fluid from the heat pumps is fixed at $40{ }^{\circ} \mathrm{C}$ and in the summer at $15{ }^{\circ} \mathrm{C}$, so the nanofluid system works for less time than the water-glycol system. Thanks to the higher efficiency of the nanofluid, the heat pumps transmit the same amount of heat as the water-glycol system more quickly and, therefore, the heat pumps will consume about $3 \%$ less electricity globally.

The second simulations confirm the increase in the heat transfer rate of the heat transfer fluid with a suspension of nanoparticles and demonstrate that its use in the HVAC 
system entails high efficiency on the performance coefficients (COP and EER) and lower heat pump energy consumptions.

In the third simulation, on the other hand, the higher efficiency of the system with external heat exchanger and nanofluid makes possible to obtain considerable savings in terms of energy consumption, which means that overall the heat pumps will run for less time.

Figure 9 shows also that the nanofluid system in the third simulation has a lower electricity consumption of about $3 \%$ compared to the other two simulations, resulting in further energy savings.

The use of nanofluid in HVAC system yields economic benefits because their use leads to a decrease in consumptions of the heat pumps and also of the pumps of the heat exchangers, in accordance with the Tiwatane and Barve's studies [53].

It can be noticed that the third simulation, with external heat exchanger has lower energy consumption than the other simulations in both seasons, confirming what was assumed at the beginning of the studies and results of the previous simulations.

\section{Conclusions}

The proposed project is one of the few works in the literature that deals with a dynamic simulation study and real application of a heat carrier fluid seeded by nanoparticles in an existing HVAC system and the theoretical simulation model with the TRNSYS software was also validated by an experimentation on the real plant in a short period of fifteen days during the winter season.

The hypothesis that gave rise to the work has been confirmed numerically and experimentally by simulations on the HVAC system and the testing of an educational building.

The nanofluid composed of water, glycol and alumina nanoparticles has a high heat transfer coefficient and can assure improved performance to HVAC systems compared to systems using water and glycol as heat transfer fluid.

The results of the simulations, carried out by means of TRNSYS 17, showed that, considering the same amount of heat released to the internal environment by the two systems under study, the use of a nanofluid in an HVAC system leads to an increase in performance of about $10 \%$.

The analysis of the experimental data obtained from the data acquisition of the thermal energy meter confirmed what was shown by the simulations. With the nanofluid there is an increase of about $10 \%$ in the performance of the HVAC system.

In addition, an analysis of the data shows that the system with external heat exchanger has an increase of about $12 \%$ in the heat transferred than systems without external heat exchanger.

The work carried out and the results obtained best represent the potential that would occur in real HVAC systems if the heat transfer fluid inseminated by nanoparticles were used and not the traditional fluid composed of water and glycol.

Author Contributions: Conceptualization, G.C., M.M. and A.d.R.; Data curation, B.R. and M.M.; Formal analysis, G.C., B.R. and M.M.; Investigation, M.M.; Methodology, G.C.; Resources, A.d.R.; Supervision, G.C. and A.d.R.; Writing-original draft, G.C. and B.R.; Writing-review \& editing, G.C., B.R. and M.M.; funding acquisition, A.d.R. All authors have read and agreed to the published version of the manuscript.

Funding: This research received financial support by HTMS srl and by Ministero dell'Istruzione, dell'Università e della Ricerca (MIUR).

Institutional Review Board Statement: Not applicable.

Informed Consent Statement: Not applicable.

Data Availability Statement: Not applicable.

Conflicts of Interest: The authors declare no conflict of interest. 


\section{References}

1. Choi, S.S.; Eastman, A.A. Enhancing thermal conductivity of fluids with nanoparticles. In Proceedings of the 1995 International Mechanical Engineering Congress and Exhibition, San Francisco, CA, USA, 12-17 November 1995; pp. 99-105.

2. Mukherjee, S.; Chakrabarty, S.; Mishra, P.C.; Chaudhuri, P. Transient heat transfer characteristics and process intensification with $\mathrm{Al}_{2} \mathrm{O}_{3}$-water and $\mathrm{TiO}_{2}$-water nanofluids: An experimental investigation. Chem. Eng. Process. Process. Intensif. 2020, $150,107887$. [CrossRef]

3. Colangelo, G.; Favale, E.; Milanese, M.; Starace, G.; de Risi, A. Experimental Measurements of $\mathrm{Al}_{2} \mathrm{O}_{3}$ and $\mathrm{CuO} \mathrm{Nanofluids}$ Interaction with Microwaves. J. Energy Eng. 2017, 143, 04016045. [CrossRef]

4. Estellé, P.; López, L.H.; Buschmann, M.H. Special Issue of the 1st International Conference on Nanofluids (ICNf19). Energies 2020, 13, 2290. [CrossRef]

5. Çobanoğlu, N.; Karadeniz, Z.H. Effect of nanofluid thermophysical properties on the performance prediction of single-phase natural circulation loops. Energies 2020, 13, 2523. [CrossRef]

6. Oh, D.-W. Thermal property measurement of nanofluid droplets with temperature gradients. Energies 2020, 13, 244. [CrossRef]

7. Lomascolo, M.; Colangelo, G.; Milanese, M.; de Risi, A. Review of heat transfer in nanofluids: Conductive, convective and radiative experimental results. Renew. Sustain. Energy Rev. 2015, 43, 1182-1198. [CrossRef]

8. Das, S.K.; Putra, N.; Theisen, P.; Roetzel, W. Temperature dependence of thermal conductivity enhancement for nanofluids. J. Heat Transf. 2003, 125, 567-574. [CrossRef]

9. Hamilton, R.L.; Crosser, O.K. Thermal Conductivity of Heterogeneous Two-Component Systems. Ind. Eng. Chem. Fundam. 1962, 1, 187-191. [CrossRef]

10. Patel, H.E.; Das, S.K.; Sundarajan, T.; Sreekumanran, N.A.; George, B.; Pradeep, T. Thermal conductivity of naked and monolayer protected metal nanoparticle based nanofluids: Manifestation of anomalous enhancement and chemical effects. Appl. Phys. Lett. 2003, 83, 2931-2933. [CrossRef]

11. Chon, C.H.; Khm, K.D.; Lee Sp Choi, S.U.S. Empirical correlation finding the role of temperature and particle size for nanofluids $\left(\mathrm{Al}_{2} \mathrm{O}_{3}\right)$ thermal conductivity enhancement. Appl. Phys. Lett. 2005, 87, 153107. [CrossRef]

12. Beck, M.P.; Yuan, Y.; Warrier, P.; Teja, A.S. The effect of particle size on the thermal conductivity of alumina nanofluids. J. Nanopart. Res. 2009, 11, 1129-1136. [CrossRef]

13. Chaji, H.; Ajabshirchi, Y.; Esmaeilzadeh, E.; Heris, S.Z.; Hedayatizadeh, M.; Kahani, M. Experimental study on thermal effi-ciency of flat plate solar collector using TiO2/Water nanofluid. Appl. Sci. 2013, 7, 60-70.

14. Al-Waeli, A.H.; Sopian, K.; Kazem, H.A.; Chaichan, M.T. Nanofluid based grid connected PV/T systems in Malaysia: A technoeconomical assessment. Sustain. Energy Technol. Assess. 2018, 28, 81-85. [CrossRef]

15. Ghadimi, A.; Saidur, R.; Metselaar, H. A review of nanofluid stability properties and characterization in stationary conditions. Int. J. Heat Mass Transf. 2011, 54, 4051-4068. [CrossRef]

16. Hwang, Y.; Lee, J.K.; Lee, C.H.; Jung, Y.M.; Cheong, S.I.; Lee, C.G.; Ku, B.C.; Jang, S.P. Stability and thermal conductivity char-acteristics of nanofluids. Thermochim. Acta 2007, 455, 70-74. [CrossRef]

17. Sun, X.-H.; Yan, H.; Massoudi, M.; Chen, Z.-H.; Wu, W.-T. Numerical simulation of nanofluid suspensions in a geothermal heat exchanger. Energies 2018, 11, 919. [CrossRef]

18. Ejeh, C.; Afga, I.; AlMansob, H.; Brantson, E.; Fekala, J.; Odiator, M.; Stanlet, P.; Anumah, P.; Onyekperem, C.; Boah, E. Computational fluid dynamics for ameliorating oil recovery using silicon-based nanofluids and ethanol in oil-wet reservoirs. Energy Rep. 2020, 6, 3023-3035. [CrossRef]

19. Lee, J.H.; Hwang, S.G.; Lee, G.H. Efficiency Improvement of a Photovoltaic Thermal (PVT) system using nanofluids. Energies 2019, 12, 3063. [CrossRef]

20. Colangelo, G.; Milanese, M.; De Risi, A. Energy simulation of a nanofluid solar cooling system in Italy. Proc. Inst. Civ. Eng. Sustain. 2019, 172, 32-39. [CrossRef]

21. Colangelo, G.; Favale, E.; Miglietta, P.; de Risi, A. Innovation in flat solar thermal collectors: A review of the last ten years experimental results. Renew. Sustain. Energy Rev. 2016, 57, 1141-1159. [CrossRef]

22. Colangelo, G.; Favale, E.; de Risi, A.; Laforgia, D. A new solution for reduced sedimentation flat panel solar thermal collector using nanofluids. Appl. Energy 2013, 111, 80-93. [CrossRef]

23. Milanese, M.; Colangelo, G.; Cretì, A.; Lomascolo, M.; Iacobazzi, F.; de Risi, A. Optical absorption measurements of oxide nanoparticles for application as nanofluid in direct absorption solar power systems-Part I: Water-based nanofluids behavior. Sol. Energy Mater. Sol. Cells 2016, 147, 315-320. [CrossRef]

24. Milanese, M.; Colangelo, G.; Cretì, A.; Lomascolo, M.; Iacobazzi, F.; De Risi, A. Optical absorption measurements of oxide nanoparticles for application as nanofluid in direct absorption solar power systems-Part II: $\mathrm{ZnO}, \mathrm{CeO}_{2}, \mathrm{Fe}_{2} \mathrm{O}_{3}$ nanoparticles behavior. Sol. Energy Mater. Sol. Cells 2016, 147, 321-326. [CrossRef]

25. De Risi, A.; Milanese, M.; Laforgia, D. Modelling and optimization of transparent parabolic trough collector based on gas phase nanofluids. Renew. Energy 2013, 58, 134-139. [CrossRef]

26. Alsalame, H.A.M.; Lee, J.H.; Lee, G.H. Performance Evaluation of a Photovoltaic Thermal (PVT) system using nanofluids. Energies 2021, 14, 301. [CrossRef] 
27. Reddy, K.S.; Kamnapure, N.R. Optical analysis and thermal management of 2-cell strings linear concentrating photovoltaic system. In Proceedings of the 11th International Conference on Concentrator Photovoltaic Systems: Cpv-11, Aix-les-Bains, France, 13-15 April 2015; AIP Publishing: College Park, MD, USA, 2015; Volume 1679, p. 110002.

28. Sardarabadi, M.; Passandideh-Fard, M.; Heris, S.Z. Experimental investigation of the effects of silica/water nanofluid on PV/T (photovoltaic thermal units). Energy 2014, 66, 264-272. [CrossRef]

29. Aksoy, Y.T.; Zhu, Y.; Eneren, P.; Koos, E.; Vetrano, M.R. The impact of nanofluids on droplet/spray cooling of a heater surface: A critical review. Energies 2021, 14, 80. [CrossRef]

30. Zhang, Z.D.; Zheng, W.; Su, Z.G. Study on diesel cylinder-head cooling using nanofluid coolant with jet impingement. Therm. Sci. 2015, 19, 2025-2037.

31. Faizan, A.; Khan, W.A. Efficiency enhancement of an air-conditioner utilizing nanofluid: An experimental study. Energy Rep. 2021, 7, 575-583.

32. Colangelo, G.; D'Andrea, G.; Franciosa, M.; Milanese, M.; De Risi, A. Dynamic simulation of a solar cooling HVAC system with nanofluid. In Proceedings of the International Conference ZEMCH2015, Lecce, Italy, 22-25 September 2015.

33. Abro, K.A.; Memon, A.A.; Hussain, S.; Khan, I.; Tlili, I. Enhancement of heat transfer rate of solar energy via rotating Jeffrey nanofluids using Caputo-Fabrizio fractional operator: An Application to solar energy. Energy Rep. 2019, 5, 41-49. [CrossRef]

34. Khullar, V.; Tyagi, H. Application of nanofluids as the working fluid in concentrating parabolic solar collectors. In Proceedings of the 37th National and 4th International Conference on Fluid Mechanics and Fluid Power 10-BN-06, Madras, India, 16-18 December 2010; pp. 1-9.

35. Du, R.; Jiang, D.; Wang, Y. Numerical investigation of the effect of nanoparticle diameter and sphericity on the thermal performance of geothermal heat exchanger using nanofluid as heat transfer fluid. Energies 2020, 13, 1653. [CrossRef]

36. Marefati, M.; Huang, W. Energy, exergy, environmental and economic comparison of various solar thermal systems using water and Thermic Oil B base fluids, and $\mathrm{CuO}$ and $\mathrm{Al}_{2} \mathrm{O}_{3}$ nanofluids. Energy Rep. 2020, 6, 2919-2947.

37. Sattar, A.; Farooq, M.; Amjad, M.; Saeed, M.A.; Nawaz, S.; Mujtaba, M.; Anwar, S.; El-Sherbeeny, A.M.; Soudagar, M.E.M.; Filho, E.P.B.; et al. Performance evaluation of a direct absorption collector for solar thermal energy conversion. Energies 2020, 13, 4956. [CrossRef]

38. Lee, S.; Choi, S.U.S.; Li, S.; Eastman, J.A. Measuring thermal conductivity of fluids containing oxide nanoparticles. J. Heat Transf. 1999, 121, 280-289. [CrossRef]

39. Balla, H.; Abdullah, S.; Faizal, W.M.W.; Zulkifli, R.; Sopian, K. Enhancement of heat transfer coefficient multi-metallic nanofluid with ansis modeling for thermophysical properties. Therm. Sci. 2015, 9, 1613-1620. [CrossRef]

40. Colangelo, G.; Favale, E.; Miglietta, P.; Milanese, M.; de Risi, A. Thermal conductivity, viscosity and stability of $\mathrm{Al}_{2} \mathrm{O}_{3}$-diathermic oil nanofluids for solar energy systems. Energy 2016, 95, 124-136. [CrossRef]

41. Jasim, Q.K.; Saleh, N.M.; Hussein, A.M. Improving thermal performance using $\mathrm{Al}_{2} \mathrm{O}_{3}$-water nanofluid in a d double pipe heat exchanger filling with porous medium. Therm. Sci. 2020, 24, 4267-4275. [CrossRef]

42. Kulkarni, D.P.; Das, D.K.; Vajjha, R.S. Application of nanofluids in heating building and reducing pollution. Appl. Energy 2009, 86, 2566-2573. [CrossRef]

43. Cao, F.; Li, H.; Zhao, L.; Bao, T.; Guo, L. Design and simulation of the solar chimney power plants with TRNSYS. Sol. Energy 2013, 98, 23-33. [CrossRef]

44. Cerezo, J.; Romero, R.J.; Ibarra, J.; Rodriguez, A.; Montero, G.; Acuña, A. Dynamic simulation of an absorption cooling system with different working mixtures. Energies 2018, 11, 259. [CrossRef]

45. Dongellini, M.; Abbenante, M.; Morini, G.L. Energy performance assessment of the heating system refurbishment on a school building in Modena, Italy. Energy Procedia 2016, 101, 948-955. [CrossRef]

46. Zakula, T.; Bagaric, M.; Ferdelji, N.; Milovanovic, B.; Mudrinic, S.; Ritosa, K. Comparison of dynamic simulations and the ISO 52016 standard for the assessment of building energy performance. Appl. Energy 2019, 254, 17. [CrossRef]

47. Aguilar-Jiménez, J.A.; Velázquez, N.; López-Zavala, R.; González-Uribe, L.A.; Beltrán, R.; Hernández-Callejo, L. Simulation of a solar-assisted air-conditioning system applied to a remote school. Appl. Sci. 2019, 9, 3398. [CrossRef]

48. Asim, M.; Dewsbury, J.; Kanan, S. TRNSYS Simulation of a solar cooling system for the hot climate of Pakistan. Energy Procedia 2016, 91, 702-706. [CrossRef]

49. Hamdani, M.; Bekkouche, S.; Benouaz, T.; Belarbi, R.; Cherier, M. The study natural ventilation by using buildings windows: Case study in a hot dry climate, Ghardaïa, Algeria. Energy Procedia 2017, 139, 475-480. [CrossRef]

50. Kai, L.C.; Mohd Zulkifly, A.; Mohd Azmil, I.; Mamat, H. Enhancement of nanofluid heat transfer in a mini-tube using SiO 2 nanoparticles. Adv. Mater. Process. Technol. 2019, 5, 607-616. [CrossRef]

51. Maxwell 2020. Available online: https://htmaterialsscience.com/images/2019/07/17/Maxwell_2020_EG_SDS.pdf (accessed on 1 December 2019).

52. Arpa Puglia. Available online: www.arpa.puglia.it (accessed on 1 September 2020).

53. Tiwatane, T.; Barve, S. Experimental study of waste heat recovery using heat pipe heat exchanger with Hybrid nanofluids: A review. Int. J. Mech. Ind. Technol. 2015, 3, 40-47. 